\title{
A Survey Of \\ Accounting Information Systems \\ Instructors' Instructional Resources \\ On The World Wide Web
}

Thomas J. Hofferd, (Email: Hofferd@Udel.edu), University of Delaware

Clinton E. White, Jr., (Email: skipw@Udel.edu), University of Delaware

\begin{abstract}
This research presents the results of an analysis of 136 randomly selected AIS faculty from the Hasselback directory and their use of Web pages to provide instructional resources (e.g. materials that add value to a course. Results indicate that $43.4 \%$ of the AIS faculty have no web presence, and $56.6 \%$ have Web pages but the majority contain only biographical information as opposed to instructional resources. Overall, the results indicate a small majority of AIS faculty are providing Web-based instructional resources.
\end{abstract}

\section{Introduction}

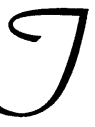

he research reported herein is based upon data gathered from the World Wide Web (Web) with reference to Accounting Information Systems (AIS) academics' presence or absence on the Web. The objective of the study is to determine the scope and extent of instructional resources found on AIS Web sites along with an indication of the type of resources.

To date there is not much research on accounting educators (in general) or AIS educators' (in particular) use of the Web to deliver education or instructional resources. There is, however, a small but growing body of empirical studies that are beginning to illuminate current practices. A unique aspect of our research is that

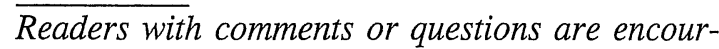
aged to contact the author via email. this is the first study to look independently at actual instructional resources provided by accounting academics on Web pages. Most, previous research has been based on surveys sent directly to accounting educators who self-report their usage of the Web for educational purposes. In contrast, this study was conducted by randomly selecting AIS educators, determining if they have a Web presence, and then evaluating their site for instructional resources. Instructional resources are generally defined as materials that support or enhance a particular course. Examples include Web-based course home pages, syllabi, PowerPoint slides, grades, lecture notes, etc.

\section{Previous Research}

A picture of the use of Internet-based resources by accounting academics is beginning to appear in the accounting literature. An early re- 
search study of 300 randomly selected U.S. accounting academics obtained a $51 \%$ response rate (154 respondents) and reported that $30 \%$ did not use the Internet for any purpose (Debreceny et al. 1996). Of the 146 respondents reporting familiarity with the Internet, $22.6 \%$ (36) reported using "Internet methods" in their classrooms. In that study, Internet methods were defined very broadly to include e-mail, searching for and downloading information from the Internet, placing information or distributing it by way of Internet servers or bulletin boards, and using the Internet to research current topics. Of those using Internet methods in their classrooms, approximately $36 \%$ reported that they use e-mail to communicate with students, while only $18 \%$ reported that they use the Web for gathering information for course projects. In this early study of the use of the Internet by accounting academics, the researchers found that out of 154 respondents, approximately $23 \%$ formally or informally used e-mail to communicate with students concerning class-related activities and used Web-based resources in the classroom (Debreceny et al. 1996).

In a more recent survey directed to accounting faculty known by their chair to be using the Internet for educational purposes, Baker and White (1999) found that $42 \%$ report using Webbased resources to support course-related activities. The researchers surveyed 714 U.S. accounting programs and received 115 usable responses from "Internet-savy" accounting educators. Most frequently, these educators report using Web pages to post course syllabi, homework assignments, class notes, and problem solutions. Less frequently they report using Web pages to provide links to additional material, post cases, provide access to tutorials and quizzes, post student pages and PowerPoint slides, and support chat rooms (Baker and White 1999).

In research designed to follow up and extend the Debreceny et al. (1996) study reported above, researchers surveyed a random sample of accounting educators in 5 countries - Australia,
Hong Kong, Singapore, the U.K., and the U.S. Response rates varied from $38 \%$ to $51 \%$. The results of this study indicate that an increasing number of accounting faculty are using "Internet methodologies," broadly defined as in the previous research to include e-mail, mailing lists, searching and downloading information from the Web, placing materials on the Web, and conferencing with students. This study reports that the vast majority of accounting faculty using Internet methodologies in instruction are using e-mail, mailing lists, and the Web. Very few are posting materials to Web servers or using more sophisticated Internet techniques (Debreceny et al. 1999).

\section{Research Methodology}

Each student in one graduate and three undergraduate Accounting Information Systems (AIS) courses was given a randomly selected page from the Prentice Hall 1998-1999 Accounting Faculty Handbook (Hasselback 1998). Using the internet, students were directed to generate random numbers, assign them to entries on their page, and investigate a total of thirty academics for use of the Web to support accounting courses. Those accounting academics that reported either a primary or secondary research interest in computers or systems were designated as an AIS educator and included in this study. Any educator not indicating such a research interest were excluded from this study.

Students visited each University or College on their page in search of each professor's Web site. If a particular professor could not be identified as an active academic at his or her University or found elsewhere on the Web, he/she was eliminated and another was randomly selected. A total of 136 useable AIS academics were included in the final pool.

\section{Web Status}

Once properly identified and qualified, each student investigated his/her selected accounting 
academics for the presence of a Web page and the instructional resources thereon. Students used the following criteria to classify what they found:

1. Determine if the professor has a Web page or is simply listed in the University's directory

2. If the professor has a Web page, determine if the page is biographical (e.g. degrees, honors, research activities, and other personal information) or if it actually contains instructional resources (e.g. syllabus, assignments, links to other resources, etc.)

3. If the Web page is classified as biographical, determine if the page is a departmental prepared page (e.g. created from a standardized template as evidenced by comparison to others in the department) or prepared by the instructor (e.g. unique, not from a template)

4. If the Web page contains instructional resources, determine what these are and classify them into standardized categorizes.

\section{Instructional Resources}

If instructional resources were found (see step 4 above), they were then classified into one or more specific categories. Instructional resources are defined in this research as follows (listed generally in order of least to more sophisticated applications):

- Class home pages - Web pages that describe an accounting course and its requirements. Such class pages were considered necessary if any other class material was included, such as;

- Course syllabus - Web pages that contain a syllabus for an accounting course;

- Class assignments - Web pages that contain daily readings or other assignments;

- Web links - Web pages that contain links to additional course and/or related professional materials;

- Course handouts - Web pages that have additional course material posted to them;
- Lecture notes - Web pages that have instructor lecture notes posted to them;

- PowerPoint files - Web pages that have PowerPoint files posted to them;

- Grades - Web pages that have student grades posted to them;

- Old quizzes or tests - Web pages that have old quizzes or tests posted to them;

- Quizzes or tests - Web pages that have quizzes or tests for students to take interactively;

- Other - Including threaded discussion groups, mailing lists, research papers, etc.

\section{Results}

The results from the survey are organized as follows. First, overall web presence or absence is reported. Next, demographic information is provided pertaining to instructor rank, credentials, years since degree completion, and their primary and secondary research interests. Instructors with a Web presence are reported next with further subdivisions for template prepared vs. individual prepared web sites. In addition a count of instructional resources found on their Web pages is also reported. Finally, detail information on the instructional resource types are provided ranked according to their frequency of appearance.

\section{Overall Web Presence}

Of the 136 AIS academics investigated, 10.3 percent (14) were found to have no presence on the web. Their existence was noted only in a basic directory listing at their institution, as shown in Table 1. Such a listing was defined as containing no more than the instructor's name, phone number, office number, and FAX number. An additional 33.1 percent (45) were found on a directory listing at their institution that we identified as having an Expanded Listing. Such expanded listing included the basic information noted above plus information such as academic degree, Professional Certification(s), courses taught, and/or research interest, as well as expanded biographical information. As distin- 
guished from a Web presence, directory listings are non-html documents. In total, 43.4 percent (59) AIS academics have no web presence of any type. The remaining 56.6 percent (77) AIS academics had some form of presence on the web. However, a presence on the web does not necessarily imply the existence of instructional resources on web sites.

\section{Instructor Rank}

Demographic rank information about the academics was obtained using both the information in Hasselback and information from their institution. The academic's rank listed in the Hasselback (1998) directory was used unless more current information was shown at the individual's institution. Table 2, Panel A indicates that 38 (27.9 percent) were full professors, 40 (29.4 percent) were associate professors, and 38 (27.9 percent) were assistant professors. The remaining 20 (14.7 percent) accounting instructors were indicated as having a rank of lecturer, instructor, or another rank. The high percentage of full professors (equal to assistant professors) was a surprise since it is normally thought that full professors compose a smaller percentage of a department than associates or assistants. Most likely this was simply a function of the sample chosen rather than an underlying condition in the population. This study did not examine the situation further.

\section{Credentials and Years Since Degree Comple- tion}

Table 2, Panel B and Panel C provide a further breakdown of the AIS' academic's demographic information. As shown in Panel B, a total of 99 (72.8 percent) AIS faculty have either a Ph.D., DBA, or are ABD. An additional 28 (20.6 percent) have either an M.B.A. or another Masters' degree. Only 9 (6.6 percent) AIS faculty have either a Bachelor's or other degree.

Table 1

Overall Directory and Web Presence

\begin{tabular}{|c|c|c|}
\hline Overall Presence & Frequency & Percen \\
\hline \multicolumn{3}{|l|}{ Systems and Computer } \\
\hline Directory Listing & 14 & $10.3 \%$ \\
\hline Expanded Listing & 45 & $33.1 \%$ \\
\hline Web Presence & 77 & $56.6 \%$ \\
\hline Total & 136 & \\
\hline \multicolumn{3}{|l|}{ All Others } \\
\hline Directory Listing & 176 & $12.3 \%$ \\
\hline Expanded Listing & 581 & $40.7 \%$ \\
\hline Web Presence & 672 & $47.0 \%$ \\
\hline Total & 1,429 & \\
\hline Grand Total & 1,565 & \\
\hline
\end{tabular}


Table 2

Demographic Information for the AIS Instructor

\section{Panel A: Primary Research Interest}

$\begin{array}{lcc}\text { Systems } & 42 & 30.9 \% \\ \text { Computer } & 28 & 20.6 \% \\ \text { Auditing } & 22 & 16.2 \% \\ \text { Financial } & 19 & 14.0 \% \\ \text { Managerial } & 15 & 11.0 \% \\ \text { Cost } & 6 & 4.4 \% \\ \text { Tax } & 1 & 0.7 \% \\ \text { Governmental } & 1 & 0.7 \% \\ \text { Behavioral } & 1 & 0.7 \% \\ \text { Advanced } & 1 & 0.7 \% \\ \text { Grand Total } & 136 \\ \text { nnn }\end{array}$

Panel B: Secondary Research Interest

$\begin{array}{lcc}\text { Systems } & 62 & 53.0 \% \\ \text { Managerial } & 19 & 16.2 \% \\ \text { Computer } & 12 & 10.3 \% \\ \text { Financial } & 7 & 6.0 \% \\ \text { Theory } & 3 & 2.6 \% \\ \text { Tax } & 3 & 2.6 \% \\ \text { Principles } & 3 & 2.6 \% \\ \text { Auditing } & 2 & 1.7 \% \\ \text { Law } & 1 & 0.9 \% \\ \text { International } & 1 & 0.9 \% \\ \text { Governmental } & 1 & 0.9 \% \\ \text { Ethics } & 1 & 0.9 \% \\ \text { Education } & 1 & 0.9 \% \\ \text { Behavioral } & 1 & 0.9 \% \\ \text { Grand Total } & 117 & \end{array}$

Panel C reports the years since degree completion for the faculty members. An interesting feature of this Panel is the number of faculty with nine or more years teaching experience -92
(67.6 percent). In this total are 31 (22.8 percent) AIS faculty members reporting more than 20 years since degree completion. These results are more interesting when considering that only 32.4 percent of the AIS faculty are relatively new to the profession with less than 9 years since degree completion.

\section{Teaching/Research Interest}

Hasselback also provides demographic information about the "Teaching/Reseach Interests" of the instructors. Four categories are listed in the Hasselback Directory - noted as 'Area 1' through 'Area 4' which represent the primary, secondary and other interest of the instructor.

Table 2, Panel D and E report the primary and secondary research interests of the sample of accounting faculty. Panel D indicates that 51.5 percent of the accounting faculty report either Systems or Computers as their primary research interest. Panel E reports an even larger percentage (63.3 percent) of the accounting faculty with such research as a secondary area. This may be indicative of a shift for many accounting faculty from a traditional accounting teaching/research model to one based on systems and information technology. Clearly one area that is at the forefront of this change is the Internet.

\section{Webpage Preparation by Rank}

Table 3 provides detail information of webpage development by academic rank. Of interest here is that though Full Professors have a larger percentage of web pages, they also have a much smaller number of pages prepared by themselves. This is important because, as we will see in Table 5, much of what is reported here is biographical information only - no instructional resources.

Examining Associate and Assistant professors, we find that there is an almost identical distribution between the two ranks with regards to 
Table 3

WebPage Preparation Detail

Overall Results

\begin{tabular}{|c|c|c|c|c|}
\hline & Template Prepared & Individual Prepared & Total & Percent \\
\hline Full professor & 16 & 8 & 24 & $31.2 \%$ \\
\hline Associate professor & 10 & 12 & 22 & $28.6 \%$ \\
\hline Assistant professor & 9 & 13 & 22 & $28.6 \%$ \\
\hline Lecturer & 3 & 2 & 5 & $6.5 \%$ \\
\hline Instructor & 2 & 1 & 3 & $3.9 \%$ \\
\hline Other & & 1 & 1 & $1.3 \%$ \\
\hline Total & 40 & 37 & 77 & \\
\hline
\end{tabular}

template versus individually prepared web sites. However, in both cases there are slightly more individually prepared as opposed to template prepared Web sites.

\section{Instructional Resource Counts}

Table 4 provides an overview of the count of instructional resources. An interesting finding is that 41.6 percent of the AIS faculty have web pages that contain only biographical information. Though AIS faculty would likely be seen as having superior technology skills, these results tend to indicate that their use of such technology for instructional purposes is somewhat limited. Another interesting finding is that $58.4 \%$ of the AIS faculty have Web pages containing one or more instructional resources. As defined above, instructional resources include course home pages with a syllabus, assignments, links to other resources, handouts, lecture notes, PowerPoint files, and old and new quizzes and tests. Each Web page was analyzed to determine how many instructional resources it contained (e.g. if it contained only a course home page with or without a syllabus, it was considered to have 1 instructional resource).

When analyzing Web pages for the number of instructional resources, we see a significantly different pattern between template prepared and individually prepared pages. Considering instructional resources on template prepared Web pages, we see that $15(33.3 \%)$ had one or more instructional resources. Of this total, $12(80 \%)$ had between one and three such resources. Compared to individually prepared Web pages, we see that $30(66.7 \%)$ had one or more instructional resources. Of this total, $24(80 \%)$ had between one and five instructional resources. Based on these data, individually prepared Web pages tend to contain more instructional resources and tend to be more sophisticated than template pages. This is consistant with our expectations. AIS instructors developing their own Web pages would tend to use more sophisticated techniques and deliver more instructional resources for their own courses.

Table 5 provides a breakdown by rank of the instructional resources. As was mentioned previously, half of the Full Professors have web pages that contain only biographical information (e.g. no instructional resources) - Panel A. This is in contrast to the Associate and Assistant Professors where only 31.8 percent have web sites with no instructional resources - Panel B \& C. Also, we note that Full professors have an equal number of template and individually prepared Web pages. This is a striking difference from 
Table4

Number of Web Sites With Instructional Resources

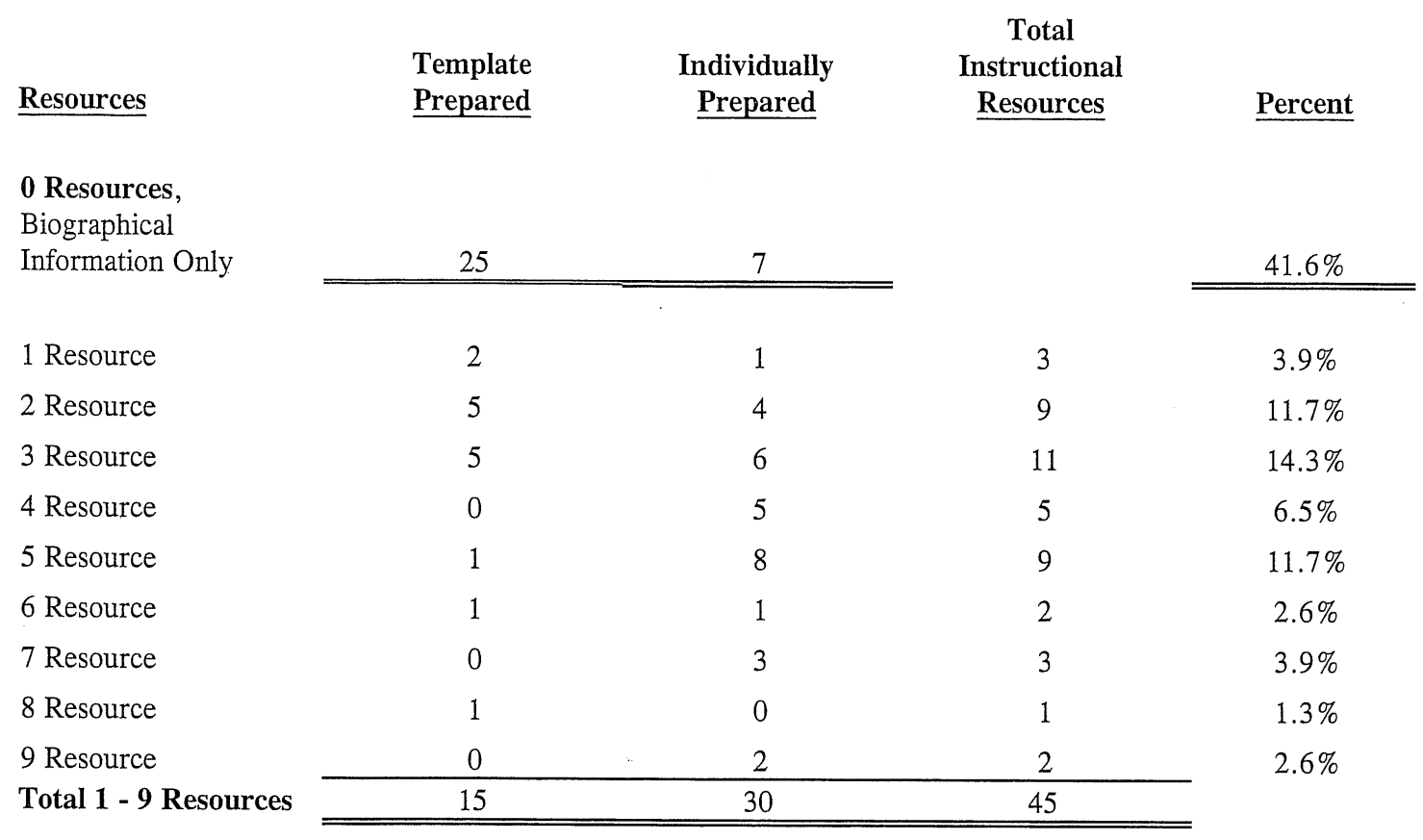

Associates, who have two times as many individually prepared pages as template prepared and Assistants who have 4 times as many.

\section{Instructional Resource Types}

A total of 45 AIS faculty were identified as having between one and nine instructional resources as discussed in Table 4 . Table 6 provides a detailed count of the number and type of instructional resources contained on these web sites. Class Web pages made up $22.6 \%$ of the total. It should be noted that there were a possible total of 10 instructional resources including the Class Web page. However, there was never a case in our sample where any of the other instructional resources were present without having a Class Web page. There were cases when the Class Web page was the only resource present. This indicates that class Web pages are the primary mechanism used by accounting faculty for delivering instructional resources.
Ranking the web sites according to number of resources provided showed natural breaks at 1-3 instructional resources, 4 - 6 instructional resources, and 7 or more instructional resources. We named these divisions: basic, intermediate, and advanced web sites.

Basic sites are those containing between one and three instructional resources. These sites amounted to 106 or 59.8 percent of the total instructional resources present (177) - Table 6. Such web sites contained a Class Web Page (22.6\%), a Syllabus $(20.3 \%)$ and Assignments $(16.9 \%)$. Examining these sites further, there was a major difference between the total sites developed using templates (31) and those sites developed by individuals (75).

Intermediate sites were identified as those with from four to six total instructional resources. Such sites had a total of 40 instructional resources $(22.5 \%)$. In addition to the instruc- 
Table 5

Number of Web Sites With Instructional Resources By Rank

\begin{tabular}{|c|c|c|c|c|}
\hline$\underline{\text { Resources }}$ & $\begin{array}{l}\text { Template } \\
\text { Prepared } \\
\end{array}$ & $\begin{array}{c}\text { Individually } \\
\text { Prepared }\end{array}$ & $\begin{array}{c}\text { Total } \\
\text { Instructional } \\
\text { Resources } \\
\end{array}$ & Percent \\
\hline \multicolumn{5}{|l|}{ Panel A: Full Professors } \\
\hline $\begin{array}{l}0 \text { Resources, Biographical } \\
\text { Information Only }\end{array}$ & 10 & 2 & & $50.0 \%$ \\
\hline 1 Resource & 1 & & 1 & $4.2 \%$ \\
\hline 2 Resource & 2 & 1 & 3 & $12.5 \%$ \\
\hline 3 Resource & 3 & 1 & 4 & $16.7 \%$ \\
\hline 4 Resource & & 2 & 2 & $8.3 \%$ \\
\hline 5 Resource & & 1 & 1 & $4.2 \%$ \\
\hline 6 Resource & & 1 & 1 & $4.2 \%$ \\
\hline 7 Resource & & & & \\
\hline 8 Resource & & & & \\
\hline 9 Resource & & & & \\
\hline Total 1 - 9 Resources & 6 & 6 & 12 & \\
\hline
\end{tabular}

Table 5

Number of Web Sites With Instructional Resources By Rank

Total

$\begin{array}{ccccc}\text { Resources } & \begin{array}{c}\text { Template } \\ \text { Prepared }\end{array} & \begin{array}{c}\text { Individually } \\ \text { Prepared }\end{array} & \begin{array}{c}\text { Instructional } \\ \text { Resources }\end{array} & \underline{\text { Percent }}\end{array}$

0 Resources, Biographical

Information Only

1 Resource

2 Resource

3 Resource

4 Resource

5 Resource

6 Resource

7 Resource

8 Resource

9 Resource

Total 1 - 9 Resources

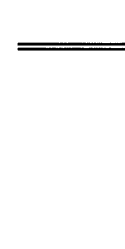

5

1

1

1

1

\begin{tabular}{lll} 
& 1 & 1 \\
1 & & 1 \\
& 1 & 1 \\
\hline
\end{tabular}


Table 5

Number of Web Sites With Instructional Resources By Rank

\begin{tabular}{|c|c|c|c|c|}
\hline Panel C: Assistant Professors & $\begin{array}{l}\text { Template } \\
\text { Prepared }\end{array}$ & $\begin{array}{l}\text { Individually } \\
\text { Prepared }\end{array}$ & $\begin{array}{c}\text { Total } \\
\text { Instructional } \\
\underline{\text { Resources }}\end{array}$ & $\underline{\text { Percent }}$ \\
\hline $\begin{array}{l}\text { 0 Resources, Biographical } \\
\text { Information Only }\end{array}$ & 6 & 1 & & $31.8 \%$ \\
\hline 1 Resource & & 1 & 1 & $4.5 \%$ \\
\hline 2 Resource & 1 & 3 & 4 & $18.2 \%$ \\
\hline 3 Resource & 1 & 1 & 2 & $9.1 \%$ \\
\hline 4 Resource & & 1 & 1 & $4.5 \%$ \\
\hline 5 Resource & & 3 & 3 & $13.6 \%$ \\
\hline 6 Resource & 1 & & 1 & $4.5 \%$ \\
\hline 7 Resource & & 2 & 2 & $9.1 \%$ \\
\hline \multicolumn{5}{|l|}{8 Resource } \\
\hline 9 Resource & & 1 & 1 & \multirow[t]{2}{*}{$4.5 \%$} \\
\hline Total 1 - 9 Resources & 3 & 12 & 15 & \\
\hline \multicolumn{5}{|c|}{$\begin{array}{c}\text { Table } 5 \\
\text { Number of Web Sites With Instructional Resources By Rank }\end{array}$} \\
\hline Panel D: All Other & $\begin{array}{l}\text { Template } \\
\text { Prepared }\end{array}$ & $\begin{array}{c}\text { Individually } \\
\text { Prepared }\end{array}$ & $\begin{array}{c}\text { Total } \\
\text { Instructional } \\
\text { Resources }\end{array}$ & $\underline{\text { Percent }}$ \\
\hline $\begin{array}{l}0 \text { Resources, Biographical } \\
\text { Information Only }\end{array}$ & 4 & 2 & & $66.7 \%$ \\
\hline \multicolumn{5}{|l|}{1 Resource } \\
\hline 2 Resource & 1 & & 1 & $11.1 \%$ \\
\hline 3 Resource & & 1 & 1 & $11.1 \%$ \\
\hline \multicolumn{5}{|l|}{4 Resource } \\
\hline 5 Resource & & 1 & 1 & $11.1 \%$ \\
\hline \multicolumn{5}{|l|}{6 Resource } \\
\hline \multicolumn{5}{|l|}{7 Resource } \\
\hline \multicolumn{5}{|l|}{8 Resource } \\
\hline \multicolumn{5}{|l|}{9 Resource } \\
\hline Total 1 - 9 Resources & 1 & 2 & 3 & \\
\hline
\end{tabular}


tional resources contained on the basic sites Web Links were included (9.0\%), Handouts (7.3\%), and Grades (6.2\%). Hence, those sites that contained from one to six instructional resources totaled 146 such resources, representing 82.5 percent of the total. Again there is a marked difference between those sites prepared using templates (7) and those prepared by the individual AIS instructor (33).

Advanced web sites contained seven or more instructional resources. These sites amounted to only 31 or 17.4 percent of the total instructional resources. Resources provided on such sites also included PowerPoint slides (5.6\%), Online Quizzes or Tests $(5.6 \%)$, Lecture Notes (5.1\%), and Old Quizzes or Tests $(1.1 \%)$. Consistent with the trend that was seen in the intermediate web sites, advanced sites prepared by the individual AIS instructor had many more resources (24) versus the web sites prepared using a template (7).

\section{Limitations}

While we examined a relatively large sample of AIS instructors, there could be instructors that were not included in our sample because of sampling problems encountered by the students. For example, if a student was able to find a listing for a faculty member but did not find their web site because the site was either password protected, hidden from the university search engine, or not linked to the faculty page, it is possible that the faculty member would be listed as not having a website when in fact one existed. No attempt was made to examine the extent of such sampling problems, though we admit that they could exist in our results. Such occurrences would indicate less sophistication or fewer web pages than actually exits. We did not examine the extent to which this may be a problem.

\section{Summary and Conclusion}

The objective of this study is to provide a broad view of how 'Accounting Information System' educators are using the Web to deliver instructional resources. AIS educators are identified by their teaching/research interests (e.g. either Systems or Computers) as reported in Hasselback (1998). Being the first study to examine

Table 6

Count of Instructional Resource Types By Preparation Type

\begin{tabular}{|c|c|c|c|c|}
\hline$\underline{\text { Resources }}$ & $\begin{array}{l}\text { Template } \\
\text { Prepared }\end{array}$ & $\begin{array}{c}\text { Individually } \\
\text { Prepared }\end{array}$ & $\begin{array}{c}\text { Total } \\
\text { Instructional } \\
\underline{\text { Resources }}\end{array}$ & $\underline{\text { Percent }}$ \\
\hline Class Web Page & 12 & 28 & 40 & $22.6 \%$ \\
\hline Syllabus & 11 & 25 & 36 & $20.3 \%$ \\
\hline Assignments & 8 & 22 & 30 & $16.9 \%$ \\
\hline Web Links & 2 & 14 & 16 & $9.0 \%$ \\
\hline Handouts & 5 & 8 & 13 & $7.3 \%$ \\
\hline Grades & & 11 & 11 & $6.2 \%$ \\
\hline PowerPoint Slides & 2 & 8 & 10 & $5.6 \%$ \\
\hline Online Quizzes or Tests & 2 & 8 & 10 & $5.6 \%$ \\
\hline Lecture Notes & 2 & 7 & 9 & $5.1 \%$ \\
\hline Old Quizzes or Tests & 1 & 1 & 2 & $1.1 \%$ \\
\hline Total & 45 & 132 & 177 & \\
\hline
\end{tabular}


existing practices, we have identified several interesting points which should provide a benchmark for future research in this area.

We identified significant differences between the activities of professors delineated by rank. Full professors are more likely to have Web sites (63.2\%) than either Associate professors $(55.0 \%)$ or Assistant professors (27.9\%). However, 50 percent of the Full professors have no instructional resources on their Web sites (e.g. their Web sites contain only biographical information). This is strikingly different from $68.2 \%$ of both Associates and Assistants who are providing instructional resources by way of their Web sites. Full professors are also more likely to have Web sites prepared by template $(50 \%)$ as opposed to individually prepared sites. By comparison, Associates and Assistants have more individually prepared than template prepared Web sites.

Individually prepared Web sites are more likely to contain instructional resources $66.7 \%$ vs. $33.3 \%$ than those sites prepared using a template. More instructional resources are also found on individually prepared Web sites. For example, a typical template prepared Web site is a class Web page with a syllabus and assignments whereas a typical individually prepared Web page is a class Web page with a syllabus, assignments, Web links to other materials, and handouts. When classified on a sophistication scale of basic, intermediate, or advanced, $69 \%$ of template prepared Web sites are basic compared to $57 \%$ of individually prepared Web sites. There was also a notable difference based on rank. In declining order, Associate professors' individually prepared Web sites had a weighted average of 4.8 instructional resources whereas Assistants had 4.3 and Fulls 4.0.

\section{Suggestions for Future Research}

Considering the increasing importance of information technology and AIS education, it seems important to monitor the existing and future trends of the use of the Web to provide instructional resources. The results reported here provide an initial look at the delivery of AIS instructional resources by way of the Web. Future research directed at monitoring the growth of this instructional medium is critical for the AIS curriculum in particular and education in general.

\section{References}

1. Baker, Richard and Clinton E. White, Jr. (1999). Internet Uses in Accounting Education: Survey Results, Journal of Accounting Education, 17(2/3), 255-266.

2. Debreceny, Roger, G. Stevenson Smith and Clinton E. White, Jr. (1996). Internet Methodologies and the Accounting Curriculum: A First Look. Accounting Perspectives, 2(1), 107-124.

3. Debreceny, Roger, Andrew Lymer, G. Stevenson Smith and C. E. White, Jr. (1999). Internet Methodologies and the Accounting Curriculum. Proceedings of the American Accounting Association, San Diego, CA.

4. Olsen, Florence. (1999). Faculty Wariness of Technology Remains a Challenge: Computing Survey Finds. Chronicle of Higher Education, October 29, A65. 


\section{Notes}

